\title{
Interactionist view of circumstances that interfere with nurses' lifestyle
}

\author{
Visão interacionista das circunstâncias que interferem no estilo de vida de enfermeiros \\ Visión interaccionista de las circunstancias que interfieren en el estilo de los enfermeros
}

\section{Anna Carolina Guimarães Braga' \\ ORCID: 0000-0002-2321-1674 \\ Glaucia Valente Valadares' \\ ORCID: 0000-0002-9263-1736 \\ Flávio Sampaio David' \\ ORCID: 0000-0002-0934-3793 \\ Lígia Santana Rosa' \\ ORCID: 0000-0001-5688-4974}

'Universidade Federal do Rio de Janeiro, Anna Nery Nursing School. Rio de Janeiro, Rio de Janeiro, Brazil.

How to cite this article: Braga ACG, Valadares GV, David FS, Rosa LS. Interactionist view of circumstances that interfere with nurses' lifestyle. Rev Bras Enferm [Internet]. 2019;72(Suppl 1):74-9. [Thematic Issue: Work and Management in Nursing]. DOI: http://dx.doi.org/10.1590/0034-7167-2017-0062

\section{Corresponding Author:}

Anna Carolina Guimarães Braga

E-mail:annacarol.braga@hotmail.com

Submission: 03-20-2017

Approval: 10-19-2017

\begin{abstract}
Objective: To analyze the circumstances interfering with nurses' lifestyle. Method: Qualitative study in light of the premises of the Grounded Theory and with theoretical reference of the Symbolic Interactionism. The study was conducted with 20 nurses from the municipality of Pinheiral, state of Rio de Janeiro. Results: The interference of work in nurses' lifestyle was unanimous and expressed by the union of the following subcategories: blaming work for sedentary habits; recording the lack of time; justifying physical/mental fatigue by the lack of healthy habits; emphasizing the financial situation; and exchanging self-care for the care of the other. Final considerations: The results showed nurses' complex life, as well as new possibilities for conducting daily choices. The need for actions that reduce the impact of workdays and contribute to these professionals incorporating a better lifestyle is noteworthy.

Descriptors: Lifestyle; Nursing; Health; Workday; Quality of Life.
\end{abstract}

\section{RESUMO}

Objetivo: Analisar as circunstâncias que interferem no estilo de vida dos enfermeiros. Método: Estudo qualitativo à luz das premissas da Teoria Fundamentada nos Dados, tendo como referencial teórico o Interacionismo Simbólico. A pesquisa foi realizada com 20 enfermeiros do município de Pinheiral, no estado do Rio de Janeiro. Resultados: Foi unânime a interferência do trabalho no estilo de vida dos enfermeiros, expressa pela união das seguintes subcategorias: culpando o trabalho pelos hábitos sedentários; registrando a falta de tempo; justificando o cansaço físico/mental pela falta de hábitos saudáveis; enfatizando a situação financeira; e trocando o cuidado de si pelo cuidado do outro. Considerações finais: Os resultados evidenciaram a complexavidade enfermeiros, assim como novas possibilidades de conduzir as escolhas diárias. Ressalta-se a necessidade de ações que reduzam o impacto das jornadas de trabalho e contribuam para que esses profissionais incorporem um melhor estilo de vida.

Descritores: Estilo de Vida; Enfermagem; Saúde; Jornada de Trabalho; Qualidade de Vida.

\section{RESUMEN}

Objetivo: Analizar las circunstancias que interfieren en el estilo de vida de los enfermeros. Método: Estudio cualitativo a la luz de las premisas de la Teoría Fundamentada en los Datos, teniendo como referencial teórico el Interaccionismo Simbólico. La investigación fue realizada con 20 enfermeros del municipio de Pinheiral, en el estado de Rio de Janeiro. Resultados: La interferencia del trabajo en el estilo de vida de los enfermeros fue unánime y expresada por la unión de las siguientes subcategorías: culpando el trabajo por los hábitos sedentarios; registrando la falta de tiempo; justificando el cansancio físico/ mental por la falta de hábitos saludables; enfatizando la situación financiera; y cambiando el cuidado de sí por el cuidado del otro. Consideraciones finales: Los resultados evidenciaron la compleja vida de los enfermeros, así como nuevas posibilidades de conducir las elecciones diarias. Se resalta la necesidad de acciones que reduzcan el impacto de las jornadas de trabajo y contribuyan a que estos profesionales incorporen un mejor estilo de vida.

Descriptores: Estilo de Vida; Enfermería; Salud; Jornada de Trabajo; Calidad de Vida. 


\section{INTRODUCTION}

The World Health Organization (WHO)(1) defines lifestyle as the set of habits and customs that can be influenced, modified, stimulated or inhibited by the prolonged process of socialization. For Almeida et $\mathrm{al}^{(2)}$, these are habits learned and adopted throughout life. It is noteworthy that the lifestyle is related to human beings immersed in a physical, social, psychological, cultural, economic, ethical, aesthetic context, so to speak, and who have a complex nature themselves, as well as multiple profiles and possibilities.

Therefore, there is no way to think of a standardized lifestyle that reduces all human beings to a choice. In other words, there is no way to determine in a single and stigmatizing form, only a way of being in the world that generates well-being and health. Lifestyle can be shaped by diverse social situations $s^{(3)}$. This can have effects both individually and collectively, since the change will be directed not only at the individual, but at the social web with which he/she interacts and thus, produces and modulates behaviors.

Lifestyle-related components may change over the years, as long as individuals value the choices they want to include or exclude from their daily lives, and perceive themselves as capable of making those changes. Habits and customs are daily actions that express and reflect daily attitudes, people's values and life opportunities. They are conscious choices (or not) and associated with each individual's perception ${ }^{(4)}$.

Thus, this study rejects the idea of lifestyle as a mere standardization and reduction of phenomena. It proposes a broader discussion about the subject, through which people can attribute meaning to their existence and re-signify experiences, which includes searching for health. However, as lifestyle and quality of life are not synonymous expressions, there is a fair concern with the correct definition of the terms used, because, although connected, they are not equal.

There is strong evidence that lifestyle changes have a major impact on the quality of life of individuals and the population ${ }^{(1,3)}$. Nowadays, this discussion is intensifying concomitantly with the so-called progress of society. Beck et al ${ }^{(5)}$ pointed out the difficulty of some workers perceiving physical and mental exhaustion resulting from work. According to the study, overload, dissatisfaction, anguish, signs of stress, and physical and mental fatigue manifest in frustration when they cannot perform all planned activities.

In order to perform their tasks, workers must have adequate environmental conditions, and it is not wise to exceed resistance limits. The Ministry of Labor requires periodic risk assessments at the work environment and of workers' health. Results of these assessments should support prevention programs such as the Environmental Risk Prevention Program (Portuguese acronym: PPRA - Regulatory Standard) and the Occupational Health Medical Control Program (Portuguese acronym: PCMSO - Regulatory Standard), which are mandatory for companies ${ }^{(6)}$.

In view of the above, the aim of this article was to analyze the circumstances interfering with nurses' lifestyle. It is part of the master's thesis entitled 'Nursing professionals and lifestyle: meanings and implications for self-care'.

This is a relevant study because all professionals who perceive their routine affected by the world must reflect on lifestyles and factors that benefit and/or harm them. Nurses must also look at themselves with a view to their growth, not only professional, but also personal growth. Therefore, it is expected that the study will allow the recognition and reflection on the factors/circumstances contributing to the adoption of an undesirable lifestyle among these professionals.

\section{OBJECTIVE}

To analyze the circumstances interfering with nurses'lifestyle.

\section{METHOD}

\section{Ethical aspects}

The study was developed in compliance with the ethical aspects of Resolution 466/2012, and approved by the Research Ethics Committee of the Anna Nery School of Nursing on November $29^{\text {th }} 2015$.

\section{Theoretical-methodological reference}

Symbolic Interactionism (SI) was adopted as theoretical reference, because it allows collaborators to be the interpreters in search of the phenomenon meaning based on the understanding and meaning of those who share their experiences. Thus, the image of the collaborator as a passive and determined organism is rejected.

The Grounded Theory (GT) was chosen as the method because it has influences from previous approaches, such as the basis of analytical induction and SI.

\section{Type of study}

A qualitative study with the objective of discovering theories based on the collected data ${ }^{(7-8)}$.

\section{Methodological procedures}

\section{Scenario of the study}

The study was conducted in 2016, in the municipality of Pinheiral, located in the countryside of the state of Rio de Janeiro.

\section{Data source}

Following the methodological rigor, data collection was performed with 20nurses of the basic and hospital network of the municipality of Pinheiral. A form for socioeconomic characterization of participants was used, and in-depth semi-structured interviews were performed individually with each one of them.

\section{Steps}

After approval by the ethics committee, the participating institutions were contacted and informed about the study. The nurses who agreed to participate signed the Informed Consent form, filled out the characterization form and then, gave the interviews. The subsequent step involved transcription, coding and analysis of collected data. 


\section{Collection and organization of data}

Interviews were performed in participants' work environment, since the schedules proposed by them and the researchers did not coincide, or some could not stay after working hours because they had other employment engagements. Data were organized in an Excel spreadsheet for easy coding and analysis.

\section{Data analysis}

The analysis was performed in three moments. The data collected from in-depth interviews were transcribed in full, which allowed three codings: open, axial and selective ${ }^{(9)}$. This occurred cyclically, as the method recommends. The first codification was the open, and carried out line by line through the vertical distribution of speeches, in which words or phrases that expressed the essence of interviewees' statements were highlighted ${ }^{(9)}$.

The second phase of the process involved the axial coding, which helps the researcher to regroup data from the open coding in a new way by originating conceptual codes. That is, connections between categories and subcategories were established by reorganizing the codes at a higher level of abstraction, and giving emphasis to precise explanations of social scene facts ${ }^{(9-10)}$.

After construction of the categories (conceptual codes), they were compared, related and interconnected according to the paradigmatic model. In their structure, there were causal conditions, phenomenon or central idea, context, intervening conditions, action-interaction strategies and consequences. This third step of the analysis involved naming and classifying the phenomenon through exhaustive data examination ${ }^{(10)}$. At this stage, it was possible to know the circumstances interfering with professional nurses' lifestyle. They will be detailed below.

\section{RESULTS}

In the first category found, are established connections with the condition of cause dictating the events, incidents and circumstances that guide the occurrence or development of a phenomenon. In other words, such a condition elucidates the elements and situations impacting on nursing professionals' lifestyle ${ }^{(9)}$.

During the interviews, professionals have demonstrated their interest in maintaining a healthy lifestyle, in spite of several limiting factors. In this category, they expressed a multiplicity of conflicting and dilemmatic feelings related to maintaining a healthy lifestyle.

The nexus with Symbolic Interactionism is noteworthy, since the collected data evidenced the professionals' interaction with their environment. Nurse makes choices with use of symbolization and reasoning in order to understand and interpret everything surrounding them by directing the choice process of an individual behavior based on specific situations, and seeking a circumstantial adaptation ${ }^{(11)}$.

In view of the above, the following cause phenomenon emerged: experiencing the multiplicity of feelings through lifestyle and selfcare. It allows the understanding of reasons influencing nursing professionals' choices of habits/customs. Next, will be presented one of the categories of this phenomenon for elucidating the relationship of work activity with lifestyle.
The repercussion of work on the lifestyle was a unanimous experience among professionals, since they feel a direct influence of their work activity on the way they live. The reports have shown quite emphatically that work often prevents them from achieving the desired changes. This category emerged from the grouping of the following subcategories: blaming work for sedentary habits; recording the lack of time; justifying physical/mental fatigue by the lack of healthy habits; emphasizing the financial situation; and exchanging self-care for the care of the other.

The first subcategory revealed that nurses blame work for sedentary habits, because it does not offer adequate conditions for professionals. Then, they see themselves obliged to fit into the imposed reality as a way to continue in the profession and fulfill the commitments, including those of budgetary order.

'Causeschedules areverybad. What can we do? Areyou going to change that work shift? No, you are not! You'll fit in, right? So, I guess professional nurses have to adapt to the imposed schedule. (Participant 5)

We need to program our personal lives, which we often have to leave behind because one has to be at work. (Participant 9)

After bad night's sleep, stressful days, heavy routine, inflexible schedules, and exhausting scales, many nurses feel depleted by fatigue, unable to reconcile work activity with their daily personal lives, and facing a compromised and work-restricted lifestyle. Therefore, if they lose their jobs, their perception will be they have lost everything, as follows:

My lifestyle? Oh, I guess I don't even have that. For my life is pretty monotonous. I only work. Then, my lifestyle is all in function of work. It depends on the time that I'm going to leave, it depends on the time that I'm going to come back. So, I cannot organize myself to do anything. (Participant 16)

An aggravating fact to this situation is that many nurses work during day and night shifts, and think about everything they have experienced at work. Thus, they are constantly anxious and keep to themselves the intense emotional load resulting from professional burnout. In this regard, some have mentioned dedicating to work a time they could use for self-care:

[...] I live a lot to work, in the morning when I wake up, I think of what I'm gonna do during the day, before sleep I think of what I did, of what I have to do tomorrow, so I think of work a lot. (Participant 6)

It's the involvement with work, really. There's no time to take care of myself. Work comes first in my life. (Participant 2)

Even in special situations, such as weekend events, they depend on their work shifts, since they do not control their schedules. Trips, family meetings and even going to the movies are subject to unexpected work activities. Hence, life is planned according to the scale of work shifts or work routine.

According to the nurses interviewed, the hours after service are dedicated to sleep and rest body and mind, because days are exhausting. According to them, the professional activity does not allow adaptation to the desired lifestyle, and this becomes a hindering factor to a healthy life. 
This is my life. LOL. Oh, I guess that's it, right?! "The fact that I work too hard prevents me from taking care of myself". (Participant 12)

Because it's work that doesn't let me lead a healthier life. It's the one to blame. The relationship would be like this: work is the main point that makes my lifestyle bad. (Participant 17)

For this reason, interviewees affirmed they regret their lack of time every day. They do not have time to attend gym, church, dedicate themselves to a religion, go out with friends and family, and several other activities, as stated below:

Unhealthy, I try to ... I would have to practice more physical activity, but I haven't been able to. And the diet, eating well is difficult because you need time to prepare your food. (Participant 6)

I guess it's my professional activity that influences my lack of time, has influence on my care. So, I don't take care of myself. (Participant 10)

Istarted a drainage massage treatment. I arranged to do it twice a week, but I already missed a session last week, 'cause I worked until late. So, this is discouraging, you know?! How can l encourage myself to start the gym, for example, if I know I won't have the time? (Participant 16)

With so many tasks at work, they reported leaving aside the social life, pleasures and needs for exclusive dedication to the profession. Not rarely, they forget they are people who interact with the world, and that this interaction promotes self-satisfaction.

The absence of healthy habits is often justified by physical/mental fatigue, which causes them to maintain the heavy pace of daily work and suffer significant bodily and mental overloads. This situation is worrying and has repercussions in the short and long term.

Actually, it's like this ... My routine affects more like this, I believe like, because of tiredness, fatigue ... I think I'm already reaching the state of burnout, really. Let me see ... I haven't had vacations, I have two overdue vacations, so I think all this ends up interfering, right? One thing that happened the other day is a fact, but you know ... the tiredness affects me directly, especially mental tiredness, like, staying ... This week, so you see, there was a day when I couldn't take it, that I lay down and slept because my eyes were heavy and I said: if I studied it wouldn't do any good, I wouldn't absorb anything [...] this tiredness affects my concentration. Mainly in the aspects of my studies and the planning of the course. (Participant 5)

That's exactly what it is. I feel very tired because of my professional role as a nurse and, at the end of the day, this makes me feel tired. (Participant 10)

In financial terms, participants voiced dissatisfaction with their salaries and the need to maintain more than one employment engagement, which puts them in a dangerous cycle. In order to have a better income, they establish more bonds and compromise the lifestyle, which has negative repercussions also on their quality of life. On the other hand, in order to maintain a minimum and desired level of comfort, including some choices, they need to improve their financial earnings. Hence, a cycle is established: more money through more work, but less and less time to enjoy the benefits.

[...] it's a pretty expensive area, ah, but eating well is expensive, eating vegetables and greens every day is expensive, fruit is very expensive. (Participant 6)

It is a full relationship, since, it's not that I don't like my job, I really like what I do, but I understand that working on shifts and also as a teacher, it's a heavy schedule. The time demand is great, the financial return is favorable, satisfactory, however, I only intend to be in this routine because the financial part is compensating. (Participant 13)

[...] and the financial issue, as we don't have so much validation, you end up looking for more than one job and with that, your routine will ... Between getting a job, making a living, and going out to a cinema, traveling, watching a film, going out, you'll pick work, right? (Participant 5)

\section{DISCUSSION}

Participants demonstrated they consider work is the main circumstance interfering with the lifestyle. They believe a better integration of professional activities with personal yearnings is crucial, since work often prevents them from fulfilling some of their desires. When nurses internalize the repercussion of work on lifestyle, it becomes symbolized as guilty for sedentary habits. Hence, the difficulty with establishing a safe limit between the time devoted to the profession and other activities becomes evident ${ }^{(12)}$.

There was consensus regarding the interference of work in participants' lives, because they are not offered adequate conditions and forced to adapt to a harmful routine, with bad night's sleep, intense emotional load and exhausting workload. As a consequence, there is no time for other activities, including self-care. Such imposition is given by the sociological systematization, since:

They see social interaction simply as a means by which the determinants of behavior begin to produce the behavior. Thus, the typical sociological systematization attributes the behavior to factors such as social position, cultural prescriptions, norms, values, sanctions, role needs and social system requirements ${ }^{(13)}$

In this context, individuals accept the working conditions in order to keep interacting socially, since the contemporary world imposes rules and status to be followed. A proof of this is their financial allegation as a pretext for accepting the reality they live. In their statements, nurses have shown the low remuneration imposes the need for other jobs, which makes them work double shifts and compromise the lifestyle and self-care.

Nevertheless, long working hours are connected both with the desire for better remuneration and the issue of 'status', since individuals feel the need to maintain their role in a society that constantly demands a better position. Thus, in order to assure their place in the contemporary world, nurses need to work harder, which harms their lifestyle both in professional and social spheres, and makes the achievement of personal desires difficult. By working exhaustively, there is no time for leisure, social relationships, varied activities, and especially for self-care (physical or mental) ${ }^{(14)}$. 
The overload generated by long working hours is associated with detrimental factors to the lifestyle. The influence of physical/mental fatigue becomes visible by the absence of healthy habits, since professionals feel exhausted to take care of themselves and perform activities that promote well-being. In addition, the shortage of free time is a factor that contributes to not incorporating healthy habits ${ }^{(12,174)}$.

Interactionism possibly explains the impact of the workday on these behaviors, since it shows nurses' understanding about the consequences of working conditions in the lifestyle in an action and reaction cycle. In other words, the meanings provided by the work elements are intrinsically fundamental for professionals' reflection on their habits, whether they are healthy or not. Therefore, it is not possible to think of a lifestyle by ignoring the meanings related to the main cause of what is being experienced ${ }^{(13)}$.

Symbolic interactionism is based on a still centered and essentialist conception of the "I", even though it is produced through social interactions ${ }^{(15)}$. Thus, by knowing that according to $\mathrm{SI}$, meaning is the product of the human interaction process, the meaning of an element is born from the way other people act towards themselves in relation to the element. Thus, SI considers the meanings are social products, creations developed in and through determinant human activities in their interactive process ${ }^{(13)}$.

Therefore, it cannot be ignored that nurses dedicate themselves to the care of the other in a way that the constructs of this interaction, the social products generated by this care also influence their lifestyle. In their reports, they verbalize they often exchange self-care for the care of others, and their satisfaction of seeing the well-being of the one being cared for. However, studies show that self-care is essential in the physical, mental and spiritual spheres as a way of qualifying the care of the other ${ }^{(16)}$.

From the statements, it becomes clear the professional practice can be harmful for professionals in all spheres if they fail to find a balance between working conditions and their own needs. The exhaustive practice of nursing without connection with self-care generates negative meanings for professionals, who feel dissatisfied with the lifestyle experienced.

\section{Limitations of the study}

Despite the importance of explaining the difficulties experienced, some nurses refused to participate in this study.

\section{Contributions to the area of nursing, health or public policy}

The study will contribute with constructs in order that researchers broaden the knowledge on the theme and consolidate some ideas about the universe of nursing professionals, namely: how they emphasize their lifestyle, how they care for themselves and establish connections. In this sense, a gap is filled in scientific research by expanding discussions and stimulating nurses holistic view.

Through this study, the nursing category can better understand itself, reflect on the choices and become aware of the necessary changes in the routine so that work activity, personal lifestyle and self-care can walk in harmony. Likewise, there will also be contributions to improve the quality of nursing care.

\section{FINAL CONSIDERATIONS}

The chosen method enabled identifying the factors and circumstances interfering with professional nurses'lifestyle, as well as the work situations that substantially modify the life habits, which are decisive in decision making for self-care.

By adopting the Grounded Theory, it was possible to reach the proposed goal, that is, to apprehend the phenomenon related to causes of the lifestyle experienced by nurses. Similarly, the theoretical reference of Symbolic Interactionism favored the understanding of meanings attributed by nurses to work environment interactions.

Moreover, it was possible to identify the contributing factors to the lifestyle experienced by the majority of participants, including dilemma conflicts related to the highlighted habits. The content of interviews allows the conclusion that nurses' work has a significant repercussion on lifestyle. The extensive workday, lack of working conditions, and fatigue caused by the exhausting routine leave them with no time and motivation for self-care. Therefore, some measures must be adopted in order to reconcile personal and professional aspects in favor of a healthier lifestyle.

In this sense, the results allow a broad reflection on nursing professionals' complex life, because they show the paradox between what nurses seek and what they actually experience. Professionals mentioned here are people who perform care, observe the impacts of carelessness with life in general, and need to deal with a very tense and challenging daily life, especially before their own lives.

This phenomenon is also an alert to the need to raise new perspectives of conducting daily choices among these professionals. Work cannot be only a way of'making a living' that results in so many losses, including one's own health. Nurses need to 'live' the life with all its inherent nuances of pleasure, desires and well-being, as they do daily in relation to other aspects of the interactive universe.

In summary, the results presented here highlight the significant need for actions for raising awareness and promoting nurses' health, so that they reflect on the impact of long working hours and other hindering factors to the adoption of a healthier lifestyle.

\section{REFERENCES}

1. WHO Centre for Health Development. A glossary of terms for community health care and services for older persons. Vol. 5 Ageing and Health Technical Report [Internet]. Kobe (JP):WHO; 2004 [cited 2016 Nov 05]. 111 p. Available from: http://apps.who.int/iris/ bitstream/10665/68896/1/WHO_WKC_Tech.Ser._04.2.pdf

2. Almeida MAB, Gutierrez GL, Marques R. Qualidade de vida: definição, conceitos e interfaces com outras áreas, de pesquisa [Internet]. São Paulo: EACH/USP; 2012 [cited 2018 Aug 26]. 142 p. Available from: http://each.uspnet.usp.br/edicoes-each/qualidade_vida.pdf 
3. Montoya LRG, Salazar ARL. [Lifestyle and good health]. Educere [Internet]. 2010 [cited 2016 Nov 05];14(48):13-9. Available from: http://www. redalyc.org/pdf/356/35616720002.pdf Spanish.

4. Portes LA. Estilo de vida e qualidade de vida: semelhanças e diferenças entre os conceitos. Lifestyle J [Internet]. 2011 [cited 2016 Nov 05];1(1):8-10. Available from: https://revistas.unasp.edu.br/LifestyleJournal/article/view/128/127

5. Beck CLC, Gonzales RMB, Stekel LMC, Donaduzzi JC. [Nursing work in critical units and its repercussion over workers' health]. Esc Anna Nery [Internet]. 2006 [cited 2016 Feb 07]; 10(2):221-7. Available from: http://www.scielo.br/pdf/ean/v10n2/a08v10n2.pdf Portuguese.

6. Battaus MRB, Monteiro MI. [Socio-demographic profile and lifestyle of workers of a metallurgical industry]. Rev Bras Enferm [Internet]. 2013 [cited 2016 Feb 18]; 66(1):52-8. Available from: http://www.scielo.br/pdf/reben/v66n1/v66n1a08.pdf Portuguese.

7. Leite JL, Silva LJ, Oliveira RMP, Stipp MAC. Thoughts regarding researchers utilizing Grounded Theory. Rev Esc Enferm USP [Internet]. 2012 [cited 2016 Feb 10];46(3):765-9. Available from: http://www.scielo.br/pdf/reeusp/v46n3/en_33.pdf English, Portuguese.

8. Torres MKL; Oliveira PC, Nunes CS, Nakayama MK. Análise da utilização da Grounded Theory (Teoria Fundamentada nos Dados) na produção científica brasileira entre 2008-2012. RBPG Rev Bras Pós-Grad [Internet]. 2012 [cited 2016 Feb 10];11(24):485-510. Available from: http://ojs. rbpg.capes.gov.br/index.php/rbpg/article/view/509/pdf

9. Strauss A, Corbin J. Pesquisa Qualitativa: técnicas e procedimentos para o desenvolvimento da teoria fundamentada. 2a ed. Porto Alegre: Artmed; 2008. 288 p.

10. Silva ECC, Ramos DLP. Interação transcultural nos serviços de saúde. Acta Bioeth. [Internet]. 2010 [cited 2016 Dec 16]; 16(2):180-90. Available from: http://www.scielo.cl/pdf/abioeth/v16n2/a11.pdf

11. Carvalho VD, Borges LO, Rêgo DP. Interacionismo simbólico: origens, pressupostos e contribuições aos estudos em Psicologia Social. Psicol Ciênc Prof [Internet]. 2010 [cited 2016 Dec 16]; 30(1):146-161. Available from: http://www.scielo.br/pdf/pcp/v30n1/v30n1a11.pdf

12. Silva AA, Rotenberg L, Fischer FM. Nursing work hours: individual needs versus working conditions. Rev Saúde Pública [Internet]. 2011 [cited 2016 Dec 16];45(6):1117-26. Available from: https://www.ncbi.nlm.nih.gov/pubmed/22124741

13. Blumer H. Symbolic interacionism: perspective and method. Englewood Cliffs (NJ): Prentice-Hall; c1969. 195 p.

14. Fernandes JC, Portela LF, Griep RH, Rotenberg L. Working hours and health in nurses of public hospitals according to gender. Rev Saúde Pública [Internet]. 2017 [cited 2016 Dec 16]; 51:63. Available from: http://www.scielo.br/pdf/rsp/v51/0034-8910rsp-S1518-87872017051006808.pdf

15. Ennes MA. Interacionismo simbólico: contribuições para se pensar os processos identitários. Perspectivas [Internet]. 2013 [cited 2016 Dec 16];43:63-81. Available from: http://seer.fclar.unesp.br/perspectivas/article/view/5956/4859

16. Ferreira ES, Souza MB, Souza NVDO, Tavares KFA, Pires AS. The importance of self-care for nursing professional. Ciênc Cuid Saúde [Internet]. 2015 [cited 2016 Dec 16];14(1):978-85. Available from: http://www.periodicos.uem.br/ojs/index.php/CiencCuidSaude/article/ view/23360/14206 